\title{
Business Development Using Business Model Canvas in Lucky Star Digital Printing
}

\author{
Aviora Karunia $^{1}$ and Bustanul Arifin Noer ${ }^{1}$
}

\begin{abstract}
Large amount of the demands for branding and spreading the information makes the business of digital printing dominate the market needs. Lucky Star located in Cepu has been operating for 5 years. Unfortunately, they do not have the right business model. To collect the data was obtain from Focus Group Discussion (FGD). Questions asked on FGD were directed to gain knowledge about the owner and employees, wants, also customers needs. Afterwards, the data were classified according to the categories of $B M C$. The researcher offered BMC hope that it can lead the business become market leader. Business model Canvas is validated using the javelin board to show that problems and the solutions are correct. The results of this study indicate that customer segments must be determined with STP (Segmenting, Targeting, Positioning) strategy. The additional value proposition is create a promo, bundling products, and add delivery services. the best channel is the "word of mouth" method. Lucky Star's additional revenue stream comes from supplier because offers products at wholesale prices. Additional key resources is give responsibility to employees for financial reports and promotion sections. In customer relation aspect, give member card for customers and providing after-sales services. Additional for key activities are Quality control, business evaluation, Promotion. In key partnerships aspect, must looking for suppliers of digital printing equipment at wholesale prices. For cost structure, need requires employees who are responsible for online financial managemen.
\end{abstract}

Keywords - Digital Printing, BMC, FGD, STP.

\section{INTRODUCTION}

Printing industry is an industry that has a rapidly changing environmental dynamics such as technological advances, changes in consumer preferences, threats of substitutes and fluctuations in raw material prices [X]. The growth of this industry is based on several things. First, the need to disseminate information widely. Second, human development in the intellectual, economic, social, educational and so on. Third, increasing population.

In Cepu, digital printing is a very widespread. One of the reason of this growth was based on Presidential Decree No. 23 of 2003 which did not require printing machine ownership certification for the establishment of a printing company. In Cepu there are more than 10 store digital printing operated. And only two store have their own printing machines, while others as intermediaries where

\footnotetext{
${ }^{1}$ Aviora Karunia and Bustanul Arifin Noer are with Department of Bussines and Management Technology, Institut Teknologi Sepuluh Nopember, Indonesia. $\quad$ Email: aviora.edu@gmail.com; bus4arifin@gmail.com.
}

orders are received will be thrown into digital printing that has a machine.

Lucky Star is a digital printing business in Cepu subdistrict that is equipped with its own printing machine and has been established since 2014. The results of Lucky Star products include banners, business cards, calendars, stickers, and so on. Based on data taken from Lucky Star, the sale of banner products is the most stable source of income. Lucky Star has 4 competitors, they already has its own advantages and when compared to its competitors, Lucky Star is not the market leader. If Lucky Star can improve this business, the market share can be enlarged, based on the large number of migrants in this region and has been a national concern since 2005 because of the "Blok Cepu".

There are some of the problems currently faced by Lucky Star. First, financial management. The problem that occurs at Lucky Star is that the price of raw materials and operational machinery is very high. Even Lucky Star itself has made efforts to get more income by increasing product prices. Second is supplier of Lucky Star. To get cheaper raw material prices and maintenance of assets, Lucky Star chose to make purchases in the cities of Semarang and Surabaya. This makes transportation expenditure increase. Transportation used is a car, because to carry these items in large quantities so it is not possible to use a motorbike. Within 1 month Lucky Star made purchases in the different cities. Third are value propositions. Lucky Star provide applying online orders. This is very helpful for customers to be able to place an order only with WhatsApp or email. But the fact happens is that consumers do not want to pay a down payment because they do not have a bank account. In addition, Lucky Star has advantages on the design side. Lucky Star customers can make design requests with cheap prices. Depending on the level of difficulty, it is just $\mathrm{Rp}$ 10.000,- until Rp 25.000,-.

From several problems that have been elaborated, it can be concluded that Lucky Star still has problems both internally and externally. These problems certainly can be solved well, so that the business that is run continues to grow. External problems cannot be changed, so companies must be able to adapt and modify business steps to suit them. Internal problems can be fixed so as not to hamper business progress. One way to grow a business is to have a business model so that Lucky Star can get to know its business and focus its business. 
Business Model Canvas (BMC) is an analytical tool for popular business models by presenting data in a simple but comprehensive way to nine essential components of the business. Although simple, BMC can help companies to get a focus on the company's perspective on the business that is being undertaken [X]. With Business Model Canvas (BMC), Lucky Star will be facilitated to remodel all forms of activities in the form of company fees and revenues. BMC has 9 components that are interrelated with each other so that when it comes to making an important decision, it is certainly easier to consider it. Focus Group discussion is used as a method of data collection. The purpose of the FGD is to explore specific problems, which are related to the topics discussed. This technique is used with the aim of avoiding the wrong meaning of the researcher on the problem under study. FGD is used to draw conclusions from intersubjective meanings that are difficult to give their own meaning by researchers because they are hindered by encouraging the subjectivity of researchers $[\mathrm{X}]$.

\section{METHOD}

There are five stages in this implementation. Which are plan the FGD topics, do FGD, analyze the data, plan the business strategy and manajerial implications. These steps will be explained and discussed in the following sections.

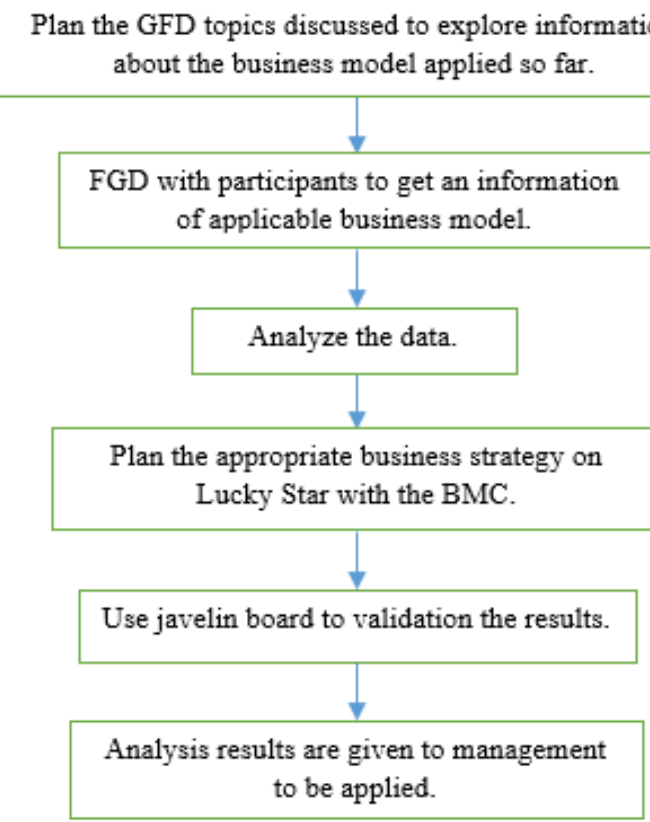

Figure 1. Research Stage

\section{A. Business Model Canvas (BMC)}

BMC analysis is an analytical model that outlines thoughts about how organizations create, provide, and capture the value of an organization. However, there are weaknesses such as ignoring the strategic objectives of the organization, not mentioning the existence of competition, and there is no priority setting in the business model. Through this approach, 9 elements will be displayed in the business model in 9 boxes. The use of BMC itself has advantages in the analysis of business models, namely being able to describe in a simple and comprehensive manner the current condition of an organization based on consumer segments, value offered, value offer paths, customer relationships, revenue streams, vital assets, cooperative partners, and cost structure owned.

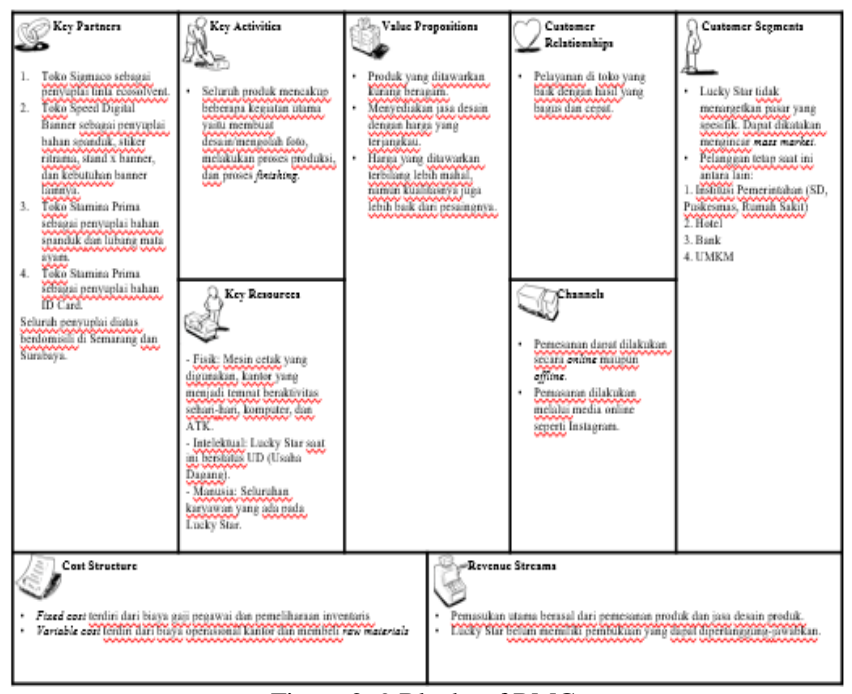

Figure 2. 9 Blocks of BMC

\section{B. Focus Group Discussion (FGD)}

The FGD method is one method of research data collection with the final results providing data derived from the results of the interaction of a number of participants in a study, as is generally the case with other data collection methods. In contrast to other data collection methods, the FGD method has a number of characteristics, including, is a method of collecting data for a type of qualitative research and the data generated comes from the exploration of social interactions that occur during the discussion process that is carried out by the informants involved

\section{RESULTS AND DISCUSSION}

\section{A. Planning a Focus Group Discussion (FGD)}

Focus groups are carried out together with 5 people, including business owners, employees, and customers. The purpose of FGD to business owners is to find out an overview of the business models that have been implemented so far. While FGD analysis to employees and customers is to determine the characteristics, behavior, needs, and desires that will be the main consideration in designing the right business model.

\section{B. The Results of FGD}

FGD involved 1 person as Lucky Star owner, 1 Lucky Star employee, and 3 customers. Questions submitted to 
the owner about the overall structure of the business model currently being implemented. As for employees about the job, the impressions and opinions of the current job. And for customers are the reasons for using services at Lucky Star, opinions about other digital printing and also expectations as a customer. The first FGD was held at:

Date : Sunday, May 18, 2019

Time : 3:00 a.m. to 5:00 p.m.

Place : Lucky Star Office

The summary of the FGD can be seen in Table 1:

TABLE 1 .

\begin{tabular}{llc}
\multicolumn{2}{c}{ SUMMARY OF FGD } \\
\hline \hline Respondent & \multicolumn{1}{c}{ Status } & Opinion \\
\hline Mr. & Owner of & The target market for my business is all
\end{tabular}

$\begin{array}{lll}\begin{array}{l}\text { Mr. } \\ \text { Agrevian }\end{array} & \text { Owner of } & \text { The target market for my business is al } \\ \text { circles, but in reality the price of my }\end{array}$

Lucky Star products is still too high for some MSME traders. Banner is one of the most sold. The price of the banner product that I controlled was a difference of 5,000 rupiah from competitors per meter, and even then the profit that I could take was only $15 \%$. The price can be very far because the printing machine I bought was a printing machine with expensive raw material. What is even more difficult is that my supplier is in a big city that is quite far away with Lucky Star offices, namely in Surabaya and Semarang.

Mr. Suyono Employee Each in this office already has a jobdesk, of Lucky even though some are not responsible so Star that the work is handled by another colleague. I am in the production section, every day I can get banner orders and the most difficult if I get a banner with big dimensions. Because the printing machine here is not large, so it must be connected again. Employees can be added but are more flexible, so they can do something that looks troublesome.

Mr. Sukron Customer Has been a Lucky Star customer since from SDN 2016. Every new school year, National 1 Jeruk Examination and other meetings that Cepu require my banner are always to Lucky Star. Besides banners, I usually order ID cards. I prefer Lucky Star because the results are fast, if in other places it's cheap but I have to wait.

Mrs. $\quad$ Customer Being a new customer for one year, since Bintang from the beginning of 2018. There have been Hotel around 6 transactions, starting from Allium brochures and banners. For banners that are Cepu used relatively long, indeed to Lucky Star. But I have another alternative if used only for programs that are temporary on other digital printing. Because the price is indeed cheaper.

Mr. Ilham Customer Bank Jateng has been a customer since from Bank 2017. Knowing Lucky Star from previous Jateng colleagues who often order here. For the price of a little difference it's important that the quality is maintained. I had tried several times to contact via WhatsApp, but the employees were not dexterous.

\section{Data analysis from FGD and visualized using BMC}

The following is the result of BMC Lucky Star analysis based on the results of the focus group with lucky star owners, employees and customers, and also literature studies on Lucky Star based on 9 BMC points.

1) Customer Segments

Based on the results of the FGD, Lucky Star does not target specific markets. Lucky Star is eyeing the mass market. Lucky Star's current regular customers include:

- Government Institutions (SD, Puskesmas, Hospitals)

- Hotel

- Bank

- MSMEs

- Broker

The MSME customer segment is not too large. For the customer segment of government institutions, hotels and banks can be said to be a promising customer segment. Unfortunately, only a few become regular customers. Based on the FGD with the owner, Lucky Star has never been directly promoting to certain customer segments. Lucky Star is only focused on selling and not paying too much attention to the customer segments that will be targeted. While for broker, it is individuals or a group that has a digital printing business but also does not have its own machine.

\section{2) Value Propositions}

Lucky Star offered design and warranty services. Lucky Star is also known for its quality prints. The services and products provided by Lucky Star can help customers solve their problems. Especially for some customers who do not have time to design their products and customers who need these products to disseminate information or at certain events. The price offered by Lucky Star in the Cepu area is expensive than competitors. But based on the results of the FGD, the difference is not a problem with the requirements to maintain quality. Lucky Star gives access to customers to place orders and complete payments online. This method is commonly done by several competitors who also apply the same thing.

\section{3) Channels}

Channels is a media company to deliver company value propositions to customer segments. Now customers can order a product in two ways. First, come to Lucky Star stores or online through WhatsApp and email. Lucky Star also using online media for sales and marketing. For now, Lucky Star has no pick-up and delivery services, all products are taken by customers to Lucky Star's office.

\section{4) Customer Relationships}

The function of customer relationships is to retain old customers and increase the number of new customers. Based on the FGD conducted with 3 Lucky Star customers, so far the strategy carried out by Lucky Star in maintaining good relations with its customers is with good service and fast results. Lucky Star uses whatsapp and email as other tools in communicating with customers. Although the use 
is only limited to receiving orders from customers. However, this can be a solution for customers who do not have time to come at store. But from the results of the FGD, customers complained that online services were not dexterous. Whatsapp is also not used for promotion.

\section{5) Revenue Streams}

Revenue streams are a vital part, where the company earns income from customers. Lucky Star benefits from product sales, including banners, business cards, calendars, stickers, and so on. The profit of each product have a different amount of profit. Lucky Star already has online financial reports to record expenses and revenues. But financial statements are irregular because there is no one who responsible for the entry and exit of the money used.

6) Key Resources

Based on the results of the FGD with the owners of Lucky Star, it can be seen that Lucky Star has the following main resources:

i. Physical: The printing press used, the office which is a place for daily activities, computers, and office stationery.

ii. Intellectual: Lucky Star is currently a UD (Trade Business) status.

iii. Humans: All employees at Lucky Star.

TABLE 2.

SUMMARY OF CURRENT SITUATION

\begin{tabular}{|c|c|}
\hline Poin BMC & Lucky Star \\
\hline \multirow{2}{*}{$\begin{array}{l}\text { Customer } \\
\text { Segment }\end{array}$} & Looking for mass market \\
\hline & $\begin{array}{l}\text { Current customers are institusions, hotel, bank, } \\
\text { MSMEs, and broker. }\end{array}$ \\
\hline \multirow{3}{*}{$\begin{array}{l}\text { Value } \\
\text { Proposition }\end{array}$} & The products offered are less diverse. \\
\hline & Providing design services at affordable prices. \\
\hline & $\begin{array}{l}\text { The price is more expensive, but the quality is } \\
\text { also better. }\end{array}$ \\
\hline \multirow[t]{2}{*}{ Channels } & Order transaction by online or offline. \\
\hline & Marketing by online media such as Instagram. \\
\hline $\begin{array}{l}\text { Customer } \\
\text { Relationships }\end{array}$ & Good service and fast results. \\
\hline \multirow[t]{2}{*}{ Revenue Streams } & $\begin{array}{l}\text { The main income comes from ordering } \\
\text { products and product design services. }\end{array}$ \\
\hline & Lucky Star does not have accountable accounts. \\
\hline \multirow[t]{3}{*}{ Key Resources } & $\begin{array}{l}\text { Physical: The printing press used, the office } \\
\text { which is a place for daily activities, computers, } \\
\text { and stationery. }\end{array}$ \\
\hline & $\begin{array}{l}\text { Intellectual: Lucky Star is currently a UD } \\
\text { (Trade Business) status. }\end{array}$ \\
\hline & Humans: All employees on Lucky Star. \\
\hline Key Activities & $\begin{array}{l}\text { All products cover several main activities, } \\
\text { namely designing / processing photos, carrying } \\
\text { out the production process, and finishing } \\
\text { processes. }\end{array}$ \\
\hline Key Partnerships & $\begin{array}{l}\text { All suppliers are domiciled in Semarang and } \\
\text { Surabaya. }\end{array}$ \\
\hline \multirow[t]{2}{*}{ Cost Structure } & $\begin{array}{l}\text { Fixed costs consist of employee salary costs } \\
\text { and inventory maintenance }\end{array}$ \\
\hline & $\begin{array}{l}\text { Variable costs consist of office operational } \\
\text { costs and buying raw materials }\end{array}$ \\
\hline
\end{tabular}

\section{7) Key Activities}

Lucky Star's simple activities are serving services and providing products requested by customers. The services and products at Lucky Star are diverse, but all of these products cover a number of main activities such as designing, processing photos, carrying out the production process, and entering the finishing process. If there are print errors or complaints, it will be handled by the business owner. Currently Lucky Star does not accept pick up and delivery services.

\section{8) Key Partnerships}

So far the key partnership of Lucky Star is with suppliers. The selection of Lucky Star suppliers is based on the price offered and the suitability of the raw materials needed. Currently Lucky Star does not have a supplier that sells all digital printing equipment. So that purchases must be made separately, Surabaya and Semarang.

\section{9) Cost Structure}

Fixed cost Lucky Star is employee salary and maintenance and repair of inventory. While the Lucky Star cost variable is the office operating costs including electricity, internet, telephone, and car fuel (BBM). Besides the cost of buying raw materials including ecosolvent ink, paper, plastic and other necessities. These costs, the amount of each month varies depending on the number of products. Lucky Star does not have financial accounting that can be accounted for so that the variable cost cannot be displayed. Table 2 will show a summary of BMC.

\section{New Business Model Canvas of Lucky Star}

With data analysis that has been carried out, it can be analyzed whether there are parts that need to be repaired or overhaul as a whole to produce a new BMC.

\section{1) Customer Segments}

Lucky Star must focus on the market being shot, so it must determine its marketing strategy with the STP (Segmenting, Targeting, Positioning) strategy.

\section{- Segmentation}

Geographical: Cepu District, Blora Regency.

Demographic: Serving companies and needs that require digital printing services and products.

Psychographics: All circles.

Behavior: Fast, easy and quality.

- Targeting

The target market approved by Lucky Star is the upper middle class. Because if you look at Lucky Star products that are the most ordered are banners while the most expensive then challengers. Acceptable by the market Lucky Star prioritizes quality from price.

\section{- Positioning}

Lucky Star must promoted to companies and those who need information tools and disseminate information such as banners, x-banners, brochures, ID cards, neon boxes, etc. with good quality, so that it fits the company's needs and according to what can be described. Products from Lucky Star are known and 
used for a long time. Lucky Star also has to provide design support and after sales services.

\section{2) Value Propositions}

In a business, fresh ideas are needed that can bring innovation. During this time Lucky Star never gave promos. Promotional products can be given to purchase certain products that have high profits. This is like what Snapy digital printing already done, they has branches in Jakarta and Surabaya, Snapy gives a discount if the customer makes a purchase with a number of parties, and for discounts on the big day. Whereas for bundling promos can be done by combining two or more different products and the prices offered are cheaper. Having access to product delivery will greatly help companies and institutions to reduce costs. Delivery can be free of charge if the purchase reaches the limit set by the company.

\section{3) Channels}

Through the results of the FGD, there were complaints about the slow completion of online transactions. Lucky Star owners must give a employee to responsibility for online bookings. The online media used by Lucky Star for promotional media is Instagram, but Lucky Star still does not look care to the content of the Instagram display. Using it as a transaction, promotion, sharing photos, videos and testimonials from customers. Increasingly tight business competition makes consumers only collect reliable information. Consumers will be more dependent on opinions from trusted sources. The communication method using word of mouth is believed to be very strong in making someone make a purchase. Promotions or recommendations that come from satisfied customers will enhance Lucky Star's reputation.

\section{4) Customer Relationships}

To retain old customers, Lucky Star must increase a sense of trust and comfort. A responsive, friendly and fast solution will be the key for Lucky Star to satisfy its customers. In addition, from the FGD results, old customers will be happier and feel they have ownership when given a member card. The member card must provide many benefits for members and also the company. Lucky Star must provide after-sales service to follow up on customer opinions about its products and to provide satisfaction to customers and create customer loyalty. Even though the transaction process is over, after-sales service must be done to maintain good relations with customers.

\section{5) Revenue Streams}

Lucky Star can promote to institutions and companies in the Cepu sub-district by distributing brochures containing discounted product information that is suitable for the promotion. Based on the results of the FGD with some Lucky Star customers, the needs of each group can be identified. For example, if Lucky Star will distribute brochures at educational institutions, then banners and ID cards will often be ordered. Another source of income that can be obtained is through partnerships. Where partners can become suppliers of raw materials, vendors, community networks, shipping services and so on. As a supplier of raw materials for example, Lucky Star can become a regular customer of the raw material supplier and the supplier will provide a special price in return for making a purchase and becoming a regular customer.

6) Key Resources

So far, the financial statements at Lucky Star have only been limited to income and expenses, and no one has been responsible for the report. We recommend that Lucky Star recruit workers who are experts in accounting. It is intended that the report on cash inflows from the results of operational activities and cash out of the costs incurred by the company can be known well how the flow of funds in the company. Employees who work at Lucky Star are graduates from Vocational High Schools (SMK). Some of them seem to lack responsibility. Likewise, Lucky Star owners are less strict with regulations. This makes company regulations seem loose and trivial. Lucky Star owners must be able to be fair leaders and be able to communicate well so that they form a solid team and can develop their business. The owner must also continue to provide guidance to train his employees to have work ethics, responsibilities and skills in serving customers.

\section{7) Key Activities}

Key activities that can be added include quality control and evaluation. In addition, Lucky Star needs to appoint employees who can carry out promotions right through available online media. Because promotion is a weapon for Lucky Star to bring in customers and generate trust from these customers. Quality control and evaluation can be carried out jointly between owners and employees so that all points of view can be seen.

8) Key Partnerships

Currently Lucky Star only works with separate raw material suppliers between Surabaya and Semarang. The distance traveled was very far. By finding a supplier of raw materials that sell in full, it can minimize transportation costs and time usage. In Surabaya there are digital printing business equipment suppliers at wholesale prices, Deprintz.

9) Cost Structure

Lucky Star must begin to pay attention to investment costs, machine depreciation costs, machine maintenance costs, operational costs, determine the cost of production, selling prices, and estimated profit and loss. financial analysis has been carried out, there are several costs that must be assumed. Are as follows: The economic age of the machine used is 5 years, the percentage of machine and equipment maintenance costs is $2 \%$, mark up by $20 \%$, it is assumed that the product sold is a 6 roll banner with a size of 2 meters $x 70$ meters. With a total of $840 \mathrm{~m}^{2}$.

TABLE 3. WORKING CAPITAL IN A YEAR

\begin{tabular}{lc}
\hline \hline Component of Production Costs & Nominal (Rp) \\
\hline Cost of reinvestasi & $20,870,000$ \\
Cost of depreciation & $12,290,000$
\end{tabular}


The $1^{\text {st }}$ International Conference on Business and Management of Technology (IConBMT)

August 3rd 2019, Institut Teknologi Sepuluh Nopember, Surabaya, Indonesia

\begin{tabular}{lc} 
Cost of maintenance & $2,067,000$ \\
Total Amount & $35,227,000$ \\
Operational cost & $168,576,000$ \\
Total cost of production & $203,803,000$ \\
\hline \hline
\end{tabular}

From the Table 3, it can be estimated that the profits and losses obtained by the company in Table 4 are as follows:

TABLE 4.

ESTIMATED LUCKY STAR PROFIT

\begin{tabular}{lc}
\hline \multicolumn{1}{c}{ Uraian } & Tahun-1 \\
\hline HPP & 20,218 \\
Total of production & 10,080 \\
Cost of production & $203,803,000$ \\
Sell Price & 25,000 \\
Total of sales & $252,000,000$ \\
PPn (10\%) & $25,200,000$ \\
Net sales & $226,800,000$ \\
Depreciation & $12,290,000$ \\
Net Income & $\mathbf{2 1 4 , 5 1 0 , 0 0 0}$ \\
EBT & $214,510,000$ \\
PPh : & \\
$0-50$ millions (10\%) & $21,451,000$ \\
$50-100$ millions (15\%) & $24,676,500$ \\
$>$ 100 j millions (30\%) & \\
Total of PPh & $46,127,500$ \\
EAT & $168,382,500$ \\
Net cash & $\mathbf{1 6 8 , 3 8 2 , 5 0 0}$ \\
\hline \hline
\end{tabular}

\section{E. Javelin Board}

Javelin board is a useful tool for validating ideas that have been formulated in nine BMC block elements. The javelin board is divided into two segments, namely the brainstorming section and the execution section. The hypothesis is divided into three parts including customer, problem, and solution.

TABLE 5.

LEFT SIDE OF JAVELIN BOARD

\begin{tabular}{|c|c|c|c|c|}
\hline \multicolumn{5}{|c|}{ Who is your customer? } \\
\hline $\begin{array}{l}\text { Cepu } \\
\text { District }\end{array}$ & $\begin{array}{l}\text { Blora } \\
\text { Regency } \\
\text { Communit } \\
\text { y }\end{array}$ & $\begin{array}{l}\text { Banks, } \\
\text { Health } \\
\text { Institutions, } \\
\text { Governmen } \\
\text { t Agencies, } \\
\text { BUMNs, } \\
\text { Hotels. }\end{array}$ & $\begin{array}{l}\text { MSME' } \\
\text { s }\end{array}$ & $\begin{array}{l}\text { Intermediar } \\
\mathrm{y}\end{array}$ \\
\hline \multicolumn{5}{|c|}{ What is the problem? } \\
\hline $\begin{array}{l}\text { Prices of } \\
\text { products } \\
\text { at Lucky } \\
\text { Star are } \\
\text { known to } \\
\text { be more } \\
\text { expensive }\end{array}$ & $\begin{array}{l}\text { There is no } \\
\text { shuttle } \\
\text { service. }\end{array}$ & $\begin{array}{l}\text { There are } \\
\text { no special } \\
\text { promos and } \\
\text { prices. }\end{array}$ & \multicolumn{2}{|c|}{$\begin{array}{l}\text { Ordering online is not } \\
\text { responded to well. }\end{array}$} \\
\hline
\end{tabular}

\begin{tabular}{|l|l|l|l|}
\hline \multicolumn{2}{|l|}{$\begin{array}{l}\text { Define the solution only after you have validated a problem worth } \\
\text { solving }\end{array}$} \\
\hline & & & \\
\hline $\begin{array}{l}\text { List the assumptions that must hold true, for your hypothesis to be } \\
\text { true. }\end{array}$ \\
\hline $\begin{array}{l}\text { Prices } \\
\text { elsewhere } \\
\text { are } \\
\text { cheaper. }\end{array}$ & $\begin{array}{l}\text { Other } \\
\text { places are } \\
\text { carried out } \\
\text { and picked } \\
\text { up. }\end{array}$ & $\begin{array}{l}\text { There's no } \\
\text { discount for } \\
\text { large } \\
\text { quantities. }\end{array}$ & $\begin{array}{l}\text { There is no time to come } \\
\text { to the place. }\end{array}$ \\
\hline
\end{tabular}

On the left hand side of the Javelin Board, several prospective customers have been determined in the BMC, some of the problems that will be dealt with and solved, and the assumptions which will support the initial hypothesis are true or false. The part of the solution is not filled because the thing that must be done at this time is determining and carrying out consumer validation and the problems at hand.

TABLE 6.

RIGHT SIDE OF JAVELIN BOARD.

\begin{tabular}{|c|c|c|c|c|}
\hline Experiments & 1 & 2 & 3 & 4 \\
\hline Customer & MSME's. & Company & Intermediary. & Institutions \\
\hline Problem & $\begin{array}{l}\text { Prices of } \\
\text { products at } \\
\text { Lucky Star } \\
\text { are known } \\
\text { to be more } \\
\text { expensive. }\end{array}$ & $\begin{array}{l}\text { There is no } \\
\text { shuttle } \\
\text { service. }\end{array}$ & $\begin{array}{l}\text { There are no } \\
\text { special promos } \\
\text { and prices. }\end{array}$ & $\begin{array}{l}\text { Ordering } \\
\text { online is not } \\
\text { responded } \\
\text { to well. }\end{array}$ \\
\hline \multicolumn{5}{|l|}{ Solution } \\
\hline $\begin{array}{l}\text { Riskiest } \\
\text { Assumption }\end{array}$ & $\begin{array}{l}\text { Prices } \\
\text { elsewhere } \\
\text { are cheaper. }\end{array}$ & $\begin{array}{lr}\text { Other } & \text { places } \\
\text { are } & \text { carried } \\
\text { out } & \text { and } \\
\text { picked up. }\end{array}$ & $\begin{array}{|ll|}\text { There's } & \text { no } \\
\text { discount } & \text { for } \\
\text { large } & \\
\text { quantities. } & \\
\end{array}$ & $\begin{array}{l}\text { There is no } \\
\text { time to } \\
\text { come to the } \\
\text { place. }\end{array}$ \\
\hline $\begin{array}{l}\text { Method \& } \\
\text { Success } \\
\text { Criterion }\end{array}$ & $\begin{array}{l}\text { Interview: } \\
7 / 10 \\
\text { Interview: } \\
70 \%\end{array}$ & $\begin{array}{l}\text { Interview: } \\
6 / 10 \\
\text { Interview: } \\
60 \%\end{array}$ & $\begin{array}{l}\text { Interview: } 7 / 10 \\
\text { Interview: } 70 \%\end{array}$ & $\begin{array}{l}\text { Interview: } \\
8 / 10 \\
\text { Interview: } \\
80 \%\end{array}$ \\
\hline $\begin{array}{l}\text { Result } \\
\text { Decision }\end{array}$ & $\begin{array}{l}7 \text { out of } 10 \\
\text { people say } \\
\text { this problem } \\
\text { is valid. }\end{array}$ & $\begin{array}{l}6 \text { out of } 10 \\
\text { people say } \\
\text { this problem } \\
\text { is valid. }\end{array}$ & $\begin{array}{|lr|}7 \text { out of } & 10 \\
\text { people say } & \text { this } \\
\text { problem } & \text { is } \\
\text { valid. } & \end{array}$ & $\begin{array}{l}8 \text { out of } 10 \\
\text { people say } \\
\text { this problem } \\
\text { is valid. }\end{array}$ \\
\hline Learning & $\begin{array}{l}\text { MSMEs } \\
\text { tend to } \\
\text { prefer other } \\
\text { digital } \\
\text { printing, } \\
\text { because } \\
\text { they think } \\
\text { the price on } \\
\text { Lucky Star } \\
\text { is } \\
\text { expensive. }\end{array}$ & $\begin{array}{l}\text { Companies } \\
\text { tend not to } \\
\text { have time to } \\
\text { have to go } \\
\text { back and } \\
\text { forth to the } \\
\text { store. }\end{array}$ & $\begin{array}{|ll|}\text { Intermediaries } \\
\text { tend to order } \\
\text { large } & \\
\text { quantities, } & \text { but } \\
\text { cannot } & \text { get } \\
\text { discounts. } & \end{array}$ & $\begin{array}{l}\text { Many } \\
\text { institutions } \\
\text { prefer to do } \\
\text { something } \\
\text { practical } \\
\text { with only } \\
\text { one come to } \\
\text { take. }\end{array}$ \\
\hline
\end{tabular}

\section{F. Analysis Results for Manajerial}

From the results of the FGD and data analysis, a recommendation emerged for Lucky Star management so that the objectives of this research could be achieved. Some recommendations that can be given regarding the results of this study are as follows: 
1. In terms of human resources that must be improved is the responsibility of the employees. Most of them have just graduated from Vocational High School, so there is no better experience to handle customers or work on their respective jobs. Lucky Star also does not have an SOP, so employees underestimate the rules. Like working hours which are sometimes underestimated. This causes a lot of work not done to the maximum and is delayed. The solution is to evaluate work regularly. Lucky Star owners must also confirm the rules in the company. If you need to provide special training. It is also necessary to hold tours together by employees to strengthen family ties.

2. In terms of marketing and relationships between customers that must be improved is how so that the media used as tools can be maximally utilized. If Lucky Star makes Instagram one of the media, then the display must be corrected and not so simple that it can show that Lucky Star is a professional business. Word-ofmouth marketing will be very good if Lucky Star can maintain relationships with customers. Therefore Lucky Star can maximize services by not only serving customers who come to the store, but customers who place orders through online. Lucky Star can also market and offer products directly to door to door and offer bundling promos and products. Promos and bundling products can be tailored to customer needs according to the results of the FGD conducted. For example, for elementary school institutions, it will be more like bundling products, namely ID cards with banners.

3. In terms of operations, the selection of suppliers will be better if there is one place. The problem is that if there are too many suppliers, it will be very time consuming and costly. Lucky Star can add new activities, namely delivering products, so that customers who do not have free time feel facilitated by this.

4. In terms of finance it's time Lucky Star is indifferent to bookkeeping and records income and expenses incurred. From here, it will be known how big / small the profits are. Even if there is a loss it will be discovered. If the business is already enlarged but there is no neat financial record, then in the future the company's financial management will be chaotic. Lucky Star owners must designate one employee who is the cashier and is responsible for finances.

\section{CONCLUSITION}

From the results of the evaluation, we found deficiencies in each BMC element and the need for a new business model in the form of BMC on Lucky Star. Business Model Canvas was created for the development of the Lucky Star business:

\section{1) Customer Segment}

Lucky Star will still target the mass market needs to first determine its marketing strategy through the STP (Segmenting, Targeting, Positioning) strategy.

2) Value Proposition

Lucky Star must fulfill the value aspect of propositions in terms of newness, customization, brand / status, cost reduction to be able to increase the value of the company.

3) Channels

Lucky Star must be more alert in dealing with customers who place orders through online media, besides that it should be noted about the platform used for promotion.

\section{4) Customer Relationship}

By giving member cards to customers, customers will feel they have benefits and attachments. The benefits of the member card can also be felt by the business owner.

\section{5) Revenue Stream}

Lucky Star can promote various customer segments to increase revenue. Other inputs are in raw material suppliers which provide lower prices than normal prices.

6) Key Resources

For human resources, Lucky Star must register its employees with employee training institutions.

7) Key Activities

Lucky Star owners should clarify the responsibilities of each employee. Lucky Star owners must also be firm with company policies.

8) Key Partnership

Must be able to get suppliers who sell everything at a low price. It would be better if Lucky Star could enter the communities to introduce its products.

9) Cost Structure

Lucky Star can make bookkeeping to find out the amount of income and expenditure so far. Additions to each element can be seen in Figure 3 
IPTEK Journal of Proceedings Series No. (5) (2019), ISSN (2354-6026)

The $1^{\text {st }}$ International Conference on Business and Management of Technology (IConBMT)

August 3rd 2019, Institut Teknologi Sepuluh Nopember, Surabaya, Indonesia

\begin{tabular}{|c|c|c|c|c|}
\hline Key Partners & Key Activities & Value Propositions & $\begin{array}{l}\text { Customer } \\
\text { Relationships }\end{array}$ & Customer Segments \\
\hline $\begin{array}{l}\text { - All Lucky Star } \\
\text { suppliers are in } \\
\text { Semarang and } \\
\text { Surabaya. } \\
\text { - Consists of } 4 \\
\text { different places. }\end{array}$ & $\begin{array}{l}\text { Make design / } \\
\text { process photos, } \\
\text { carry out the } \\
\text { production } \\
\text { process, and } \\
\text { finishing } \\
\text { process. }\end{array}$ & $\begin{array}{l}\text { - Providing } \\
\text { design services } \\
\text { at affordable } \\
\text { prices. } \\
\text { - The quality is } \\
\text { also better than } \\
\text { its }\end{array}$ & $\begin{array}{l}\text { Good service } \\
\text { with fast } \\
\text { results. }\end{array}$ & $\begin{array}{l}\text { Lucky Star } \\
\text { eyeing mass } \\
\text { market. }\end{array}$ \\
\hline & & competitors. & & \\
\hline New Key Partners & New Key Activities & $\begin{array}{l}\text { New Value } \\
\text { Propositions }\end{array}$ & $\begin{array}{l}\text { New Customer } \\
\text { Relationships }\end{array}$ & $\begin{array}{l}\text { New Customer } \\
\text { Segments }\end{array}$ \\
\hline $\begin{array}{l}\text { - Looking for } \\
\text { suppliers of } \\
\text { digital printing } \\
\text { business }\end{array}$ & $\begin{array}{l}\text { - Quality } \\
\text { control and } \\
\text { business } \\
\text { evaluation. } \\
\text { - Promotion. }\end{array}$ & $\begin{array}{l}\text { - Making promo } \\
\text { and bundling } \\
\text { products. }\end{array}$ & $\begin{array}{l}\text { - Card members } \\
\text { to customers. } \\
\text { - Good service } \\
\text { through online. }\end{array}$ & $\begin{array}{l}\text { - Determine } \\
\text { the target } \\
\text { market with } \\
\text { STP strategies }\end{array}$ \\
\hline $\begin{array}{l}\text { wholesale } \\
\text { prices. }\end{array}$ & & shuttle services. & $\begin{array}{l}\text { after-sales } \\
\text { services. }\end{array}$ & \\
\hline \multicolumn{2}{|l|}{ Key Resources } & \multicolumn{3}{|l|}{ Channels } \\
\hline \multirow{2}{*}{\multicolumn{2}{|c|}{$\begin{array}{l}\text { - Physical: The printing press } \\
\text { used, the office which is a place } \\
\text { for daily activities, computers, } \\
\text { and stationery. } \\
\text { - Intellectual: Lucky Star is } \\
\text { currently a UD (Trade Business) } \\
\text { status. } \\
\text { - Humans: All employees on } \\
\text { Lucky Star. }\end{array}$}} & \multicolumn{3}{|c|}{$\begin{array}{l}\text { - Reservations can be made online or offline. } \\
\text { - Marketing is done through online media such as } \\
\text { Instagram. }\end{array}$} \\
\hline & & \multirow{3}{*}{\multicolumn{3}{|c|}{$\begin{array}{l}\text { - Pay attention to each order both through } \\
\text { offline and online. } \\
\text { - Start promoting and creating interesting } \\
\text { content on social media. } \\
\text { - The word of mouth method is a very } \\
\text { powerful method. }\end{array}$}} \\
\hline \multicolumn{2}{|l|}{ New Key Resources } & & & \\
\hline \multicolumn{2}{|c|}{$\begin{array}{l}\text { - Give responsibility to } \\
\text { employees for financial reports } \\
\text { and promotion sections. }\end{array}$} & & & \\
\hline Cost Structure & New Cost Structure & Revenue Streams & \multicolumn{2}{|l|}{ New Revenue Streams } \\
\hline $\begin{array}{l}\text { - Fixed Cost } \\
\text { - Variable Cost }\end{array}$ & $\begin{array}{l}\text { Examples of } \\
\text { recorded } \\
\text { monthly } \\
\text { expenses are } \\
\text { given. }\end{array}$ & $\begin{array}{l}\text { The main } \\
\text { income comes } \\
\text { from ordering } \\
\text { products and } \\
\text { product } \\
\text { design } \\
\text { services. }\end{array}$ & \multicolumn{2}{|c|}{$\begin{array}{l}\text { Start cooperating and promoting } \\
\text { potential institutions and } \\
\text { companies to get more income. } \\
\text { Partnerships such as suppliers of } \\
\text { raw materials can provide } \\
\text { rewards for making purchases } \\
\text { and becoming regular customers. }\end{array}$} \\
\hline
\end{tabular}

Figure 3. BMC evaluation

\section{REFERENCES}

Use the "Insert Citation" button to add citations to this document. 